\title{
Podsolic and hydromorphic soils on a coastal plain in the Cameroon Republic
}

\author{
W. J. BRZESOWSKY \\ Former Soil Scientist with the Cameroons Development Corporation, \\ Cameroon Republic
}

\begin{abstract}
Summary
The presence of typical podsols and podsolic soils in the hot humid tropical lowlands is reviewed and discussed in connection with the occurance of podsolic soils which are part of a hydrological sequence on a coastal plain in the Cameroon Republic.
\end{abstract}

\section{Introduction}

There is much accumulated evidence available at present that typical podsols and podsolic soils are not restricted to the temperate regions but that they can be found under certain conditions in the hot humid tropical lowlands.

MOHR and VAN BAREN (1954) have reviewed and discussed in detail the presence of some humus-iron and humus podsols developed on pervious quartz sands. The parentmaterial void of any weathering mineral or clayey elements favoured an easy transport of humus materials and such iron-oxides as happened to be present. From the summarised data it also becomes apparent that the ground-water level has played a decisive rôle in the formation of these podsol soils, i.e. by enrichment of the Bhorizon with humus and/or sesquioxides under conditions of temporary submerging after heavy tropical rains.

This has recently also been reported by AHN (1959) who noticed the presence of humus podsols developed on infillings of fine marine sands covering lower lying sites (former lagoons) along the coast of S.W. Ghana and which are subject to temporary waterlogging after heavy rains. These deposits including sand derived from granite parent-rock and resorted material from tertiary sand deposits are likely to be of a high acidity.

In the Ivory Coast (DABIN et al.) iron-humus podsols are described developed on very permeable tertiary sands ("sols hydromorphes minéraux") but also on recent (holocene) marine sands which cover depressions along the coast ("sols peu évolués"). On marshy alluvial flats humus podsols have developed because of an enhanced humification under permanent waterlogged conditions.

EDELMan visiting the Cameroon Republic noticed ground-water podsols situated on a lower lying site of the terrain and developed on leached sandy deposits.

VAN SCHUYLENBORGH (1957) classifying soils in Indonesia at low altitudes (0-100 meters above sea-level) and developed on highly acidic parent-material discussed a catena of soils respectively belonging to the Podsolised Latosolic, the Red-Yellow

Received for publication 2nd January, 1962. 
and Yellow Podsolic Soil Group, the latter being more liable to a temporary high ground-water level than the former.

From the foregoing it becomes apparent that in the hot humid tropical lowlands such soil-forming factors as micro-relief and the nature of the parent-material may, in combination with impeded drainage or temporary waterlogging, as frequently experienced after heavy tropical rainshowers (see also PAPAdAKIs, 1960), create favourable conditions for the formation of typical podsols or podsolic soils.

This has been further substantiated by the work of VAN DER VOORDE (1957) and VAN DER EYK (1957) in Surinam and that of EVRARD (1957) in the former belgian Congo.

In the temperate regions it is found (RuSsell and RuSSELL, 1956; JENNY, 1941) that under conditions of rising ground-water level the translocation of sesquioxides and/or humus may gradually diminish. In extreme cases where a complete submergence of the mineral horizons occurs, hydromorphic soils may be formed.

Existing differences in drainage conditions as a result of micro-relief may thus create a sequence of genetically different soil types.

This is likely to occur most intensively in regions of relative moderate rainfall, where the land surface as a consequence tends to be more mosaic. A sequence of genetically different soil types may occur even within a restricted distance.

In an attempt to classify soils present in the immediate vicinity of the Cameroon Mountain, in the following some profiles which are part of a hydrological sequence, are described and discussed on basis of the profile morphology and available chemical data.

\section{Location}

The area under review forms part of the TIKO Coastal plain and is situated between the Mungo and Essoasso Rivers.

The coastal plain steeply rises out of the mangroves and gradually slopes up to $300 \mathrm{ft}$. The altitude of the area amounts to $60-160 \mathrm{ft}$. The area is level and normal to sub-normal in relief. There are no major rivers present but only a few little streams which are hardly cut in.

When the area was taken into cultivation an extensive drainage system was made to drain off the lower sites. The area has been covered previously by secondary forest.

\section{Climate}

The climate is characterised by a main rainy season with on average lower maximum temperatures, preceded and succeeded respectively by an early and late rainy season, both having on average higher maximum temperatures. A dry season with very little rainfall commenses usually in November/December and extends into March-April. This is shown in TABLE 1 .

\section{Soils}

The soils covering the area and which are in general of a rather uniform fine texture appear to be strongly acidic.

It is thought that these soils, being re-deposited during the quaternary era (Hasselo, 
TABLE 1 .

\begin{tabular}{|c|c|c|c|c|}
\hline & \multirow{2}{*}{$\begin{array}{l}\text { Rainfall } \\
\text { in } \mathrm{mm}\end{array}$} & \multicolumn{2}{|c|}{ Temperature in ${ }^{\circ} \mathrm{F}$} & \multirow{2}{*}{$\begin{array}{l}\text { Relative } \\
\text { humidity }\end{array}$} \\
\hline & & $\max$. & $\min$. & \\
\hline January & 15,8 & 90,0 & 71,3 & 79 \\
\hline February $\ldots \ldots$ & 38,0 & 92,4 & 72,2 & 77 \\
\hline March . & 78,5 & 98,0 & 71,5 & 80 \\
\hline April $\ldots$ & 259,3 & 104,1 & 71,7 & 80 \\
\hline May $\ldots \ldots \ldots$ & 194,5 & 101,2 & 70,0 & 81 \\
\hline$\ldots \ldots$ & 242,0 & 95,9 & 71.5 & 84 \\
\hline July $\ldots \ldots$ & 605,5 & 89,1 & 71,3 & 90 \\
\hline August $\ldots$ & 565,0 & 84,2 & 70,8 & 92 \\
\hline September .... & 386,0 & 86,6 & 70,6 & 87 \\
\hline October . & 181,0 & 92,3 & 70,5 & 82 \\
\hline November .... & 65,8 & 92,8 & 70,5 & 82 \\
\hline December .... & 21,3 & 87,9 & 70,0 & 82 \\
\hline Total & 2652,7 & & & \\
\hline
\end{tabular}

1961), are of a tertiary origin. These pleistocene deposits have thus been thoroughly weathered and leached already in tertiary times which explains the high acidity.

A few little hills covered by surface laterite hardpans and concretional hard layers and rounded off basaltic and coarse grained ultra-basic rocks, are present in the area. Locally, fragments derived from the weathering ante-quaternary tuffs may have been mixed through the pleistocene deposits to some extent.

A few narrow strips of sandy dried up holocene riverbeds and wider strips of sandy soils not necessarily to connect with present streams, but most likely be waterlaid during the quaternary marine transgression, are present. Their acreage is however limited as compared with the more fine textured soils.

Generally speaking it appears that slight differences in micro-relief have caused the main differences (e.g. drainage) between the distinguished soil series occuring on the coastal plain. Thus, heavily mottled and waterlogged gleys or pseudo-gleys cover the low-lying sites, whereas dark brown to yellowish-brown well drained soils cover the high-lying sites. Between these two extremes, moderately well drained and moderately drained soils are present in the range of the sequence.

Examination of the aerial photographs of the area revealed that the differences in drainage as defined by the classification are well explicable by the differences in micro-relief.

For a full appreciation of the mosaic pattern in the field is referred to the soIL MAP of the area under review.

\section{Profile description and analytical data}

The results obtained from the profile investigation are summarised hereunder. Horizon samples were taken from a profile situated on a well drained site and chemically analysed (TABLE 2).

Granular analysis data are not available. It is thought however that because of the great similarity in the nature and deposition of the soils covering the area, the error in assessing the textural classes of the different horizons may not have been too great (DABIN et al.). 
SoIL MAP

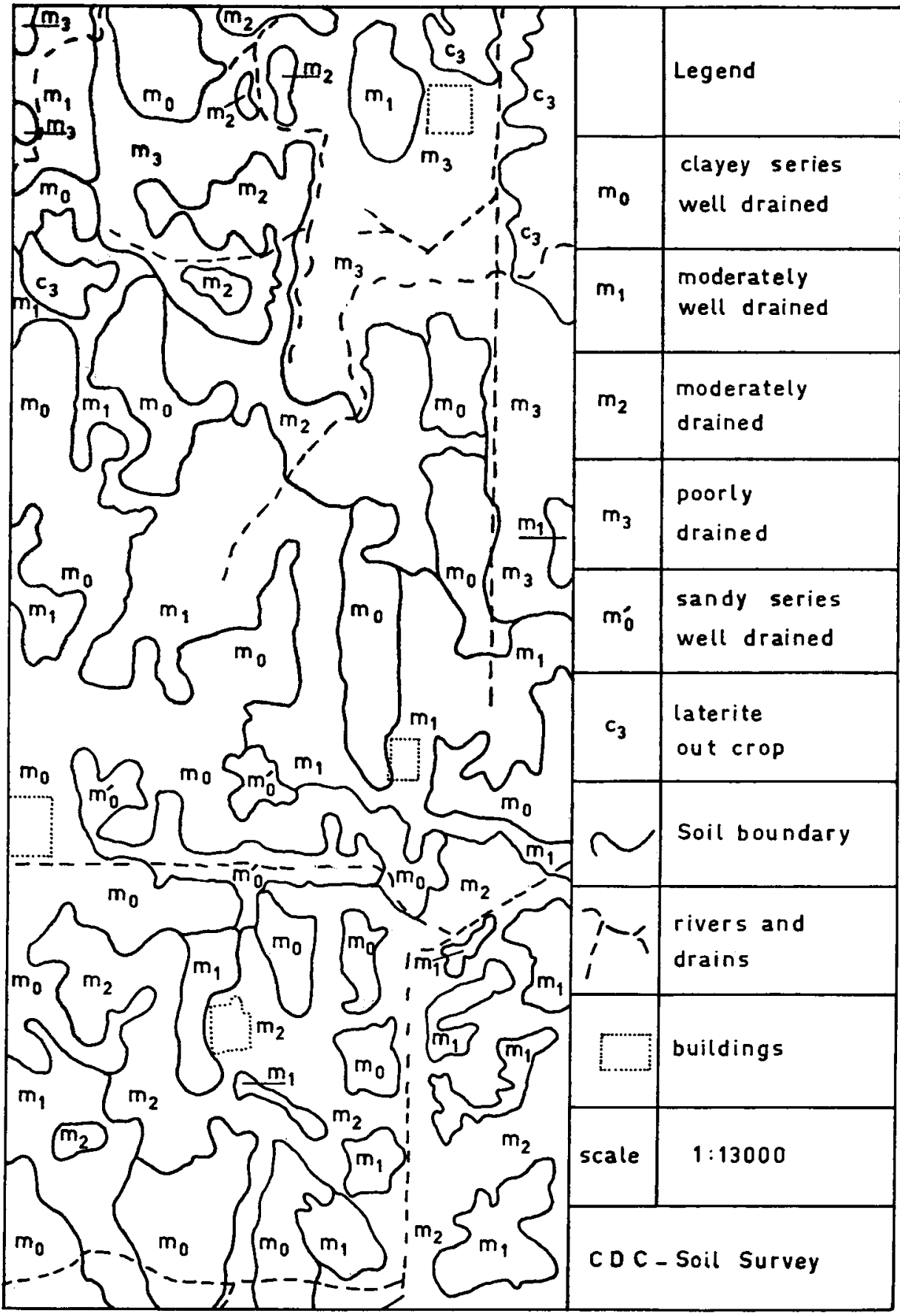


PODSOLIC AND HYDROMORPHIC SOILS ON A COASTAL PLAIN...

TABLE 2. Chemical data from a profile on a well drained site ${ }^{1}$

\begin{tabular}{|c|c|c|c|c|}
\hline Horizon in $\mathrm{cm}$ : & $\begin{array}{l}0-30 \\
\left(\mathbf{A}_{1}\right)\end{array}$ & $\begin{array}{l}30-50 \\
\left(\mathrm{~A}_{2}\right)\end{array}$ & $\begin{array}{c}50-90 \\
\left(\mathrm{~B}_{2}\right)\end{array}$ & $\begin{array}{c}90-120 \\
\left(\mathrm{~B}_{3}\right)\end{array}$ \\
\hline $\begin{array}{l}\text { \% Organic Matter } \\
\text { (Walkley-Black) }\end{array}$ & 1,921 & 0,380 & 0,310 & 0,211 \\
\hline $\begin{array}{l}\text { pH- } \mathrm{H}_{2} \mathrm{O} \\
1: 2,5\end{array}$ & 5,55 & 4,82 & 5,30 & 4,85 \\
\hline$\ldots \ldots \ldots \ldots \ldots \ldots \ldots$ & 4,40 & 3,72 & 3,75 & 3,74 \\
\hline $\begin{array}{l}\text { Cat. exchange potential } \\
\text { m.e. } / 100 \mathrm{~g} \text { soil }\end{array}$ & 13,52 & 11,20 & 15,76 & 14,24 \\
\hline $\begin{array}{l}\text { Total exchange potential } \ldots \ldots \ldots \\
\text { m.e. } / 100 \mathrm{~g} \text { soil }\end{array}$ & 5,92 & 3,36 & 6,32 & 5,12 \\
\hline$\% \mathrm{Ca}$ & 0,172 & 0,093 & 0,181 & 0,103 \\
\hline$\% \mathrm{Mg}$ & 0,208 & 0,036 & 0,010 & 0,026 \\
\hline ppm $\mathbf{K}$ & 2,19 & 2,50 & 1,31 & 0,75 \\
\hline ppm $\mathrm{Na}$ & 0,69 & 0,63 & 0,63 & 0,56 \\
\hline
\end{tabular}

1 Chemical analysis carried out at Ibadan, Nigeria.

(i). Profile on a well drained site

Vegetation: grasses, bananas and shrubs (abandoned land).

Profile description ${ }^{1}$ :

$A_{1} \quad 0-30 \mathrm{~cm}$ : Dark brown (10 YR 4/3) medium-fine clayey sand $(100-500 \mu)$; coarse structure, moderate; friable.

$A_{2} \quad 30-50 \mathrm{~cm}$ : Boundary diffuse undulate; Yellowish-brown $(10 \mathrm{YR} 5 / 4)$ coarse very sandy clay $(100-1000 \mu)$; medium sub-angular blocky, weak; friable.

$B_{2} \quad 50-90 \mathrm{~cm}$ : Boundary diffuse, nearly plain; Yellowish-brown $(10$ YR 5/4) sandy clay to clay; fine angular blocky, strong; firm consistence; strongly developed clay coatings present.

B $_{3} \quad 90-120 \mathrm{~cm}$ : Boundary diffuse smooth; Yellowish-brown $(10$ YR 5/4) medium-fine sandy clay $(100-500 \mu)$; coarse sub-angular blocky, strong; firm consistence; very weakly developed clay coatings present.

Conditions of alternating oxidation and reduction occur below $120 \mathrm{~cm}$ depth. The profile is well rooted and few roots are still present up to $90 \mathrm{~cm}$ depth.

(ii). Profile on a very poorly drained site

Vegetation: see under (i).

Profile description ${ }^{1}$ :

$A_{11} \quad 0-15 \mathrm{~cm}$ : Dark brown (10 YR 3/3) sandy loam, fine crumb; friable.

$\mathrm{A}_{12}$ 15-30 $\mathrm{cm}$ : Pale brown (10 YR 6/3) sandy loam, fine crumb ; friable ; distinct rust mottling (5 YR 4/8) and faint-grey mottling (10 YR 6/1) present.

1 The Munsell colour notation is based on field-wet determination.

Neth. J. agric. Sci., Vol. 10 (1962) No. 2 (May) 
$B_{1} \quad 30-50 \mathrm{~cm}$ : Light brownish-grey $(10 \mathrm{YR} 6 / 2)$ very sandy clay; mod. fine sub-angular blocky; prominent rust and grey mottling present.

$\mathbf{B}_{2 \mathrm{~g}} 50-60 \mathrm{~cm}$ : Light grey to grey $(10 \mathrm{YR} 7 / 1-6 / 1)$ sandy clay, massive structure; the grey aggregates are mottled with rust.

$+60 \mathrm{~cm}:$ Waterlogged.

The waterlogged conditions do occur for a greater part of the year.

\section{Discussion}

From the profile description it becomes apparent that in case of the better drained soil series ( $\mathbf{M}_{0}$ on the soIL MAP) a layer of maximum clay accumulation has developed at a depth between $50-90 \mathrm{~cm}\left(\mathrm{~B}_{2}\right)$. An increase in the clay content occurs downwards the profile and reaches a maximum in the above horizon, indicating a podsolisation process.

The upper horizons are characterised by a moderate crumb to weak sub-angular blocky structure, which points into the same direction. The consistence increases also from the $\mathrm{A}$ to the B-horizon.

Clay coatings are strongly developed in the $\mathrm{B}_{2}$-horizon, but only very weakly developed in the $B_{3}$-horizon and absent in the upper horizons.

In the temperate regions claypan formation is one of the characteristics of mature brown earths, i.e. the well drained soils under "mull", well known as gray-brown podsolics.

Investigations have revealed that in case of the gray-brown podsolics, the zone of relative enrichment of aluminium corresponds with the zone of clay enrichment (RusSELL and RUSSELL, 1956). It does however not necessarily imply a higher $\mathrm{Al}_{2} \mathrm{O}_{3}$ / $\mathrm{Fe}_{2} \mathrm{O}_{3}$-ratio in that particular layer as compared with the upper layers.

In this respect VAN SchUYLENBORGH and TAN have drawn the attention to the rôle of the $\mathrm{C} / \mathrm{N}$-ratio in soil formation, i.e. in connection with the solubility and mobility of aluminium and iron (van SchUYLEnborgh, 1957, 1958; TAN and van SchuYlenBORGH, 1961).

Thus, a constant $\mathrm{C} / \mathrm{N}$-ratio in the soil profile corresponds with a complete decomposition of organic matter into carbon dioxide and water, whereas a decreasing $\mathrm{C} / \mathrm{N}$ ratio with increasing depth may signify the humification of organic matter. In the latter case complex iron-compounds are formed which are more soluble than the aluminium-compounds. It results in a decreasing $\mathrm{Al}_{2} \mathrm{O}_{3} / \mathrm{Fe}_{2} \mathrm{O}_{3}$-ratio with increasing depth of the soil profile.

In the former case however, soil formation takes place mainly under influence of released carbon dioxide and consequently relative more aluminium becomes mobile as compared with iron.

According to the above authors the latter is the case in the podsolic soils of the humid tropics, where $\mathrm{Al}_{2} \mathrm{O}_{3} / \mathrm{Fe}_{2} \mathrm{O}_{3}$-ratios normally increase with depth of the soil profile.

As may be concluded from TABLE 1 , it is not very likely that under these conditions humification of organic matter occurs (MOHR and VAN BAREN, 1954). LaUdelout et al. (1960) consider the optimum temperature for humus synthesis also to be lower than those commonly occuring in tropical soils.

Since unfortunately no fundamentally important data are available to indicate a similar trend of the $\mathrm{Al}_{2} \mathrm{O}_{3} / \mathrm{Fe}_{2} \mathrm{O}_{3}$-ratio in case of the well drained soil series, the dif- 
ferences between the measured $\mathrm{pH}-\mathrm{H}_{2} \mathrm{O}$ and $\mathrm{pH}-\mathrm{KCl}$ in the different horizons may serve as an indication for this phenomenon. This is summarised in TABLE 3.

TABLE 3.

\begin{tabular}{ccccc}
\hline Horizon & $\mathrm{pH}-\mathrm{H}_{2} \mathrm{O}$ & $\mathrm{pH}-\mathrm{KCl}$ & $\begin{array}{c}\text { Absolute difference } \\
\mathbf{p H}-\mathrm{H}_{2} \mathrm{O}-\mathrm{pH}-\mathrm{KCl}\end{array}$ & $\begin{array}{c}\text { In \% of } \\
\mathrm{pH}-\mathrm{H}_{2} \mathrm{O}\end{array}$ \\
$\mathbf{A}_{1}$ & 5,55 & 4,40 & & 20 \\
$\mathrm{~A}_{2}$ & 4,82 & 3,72 & 1,15 & 23 \\
$\mathbf{B}_{2}$ & 5,30 & 3,75 & 1,10 & 30 \\
$\mathbf{B}_{3}$ & 4,85 & 3,74 & 1,55 & 23 \\
\hline
\end{tabular}

Although the $\mathrm{pH}-\mathrm{H}_{2} \mathrm{O}$ of the $\mathrm{A}_{1}, \mathrm{~A}_{2}$ and $\mathrm{B}_{3}$-horizons differs significantly, the absolute differences are about equal, but much lower than in the $\mathrm{B}_{2}$-horizon. The same applies to the absolute differences expressed as a percentage of $\mathrm{pH}-\mathrm{H}_{2} \mathrm{O}$.

The above results seem to suggest that the potential soil acidity is the greatest in the $\mathrm{B}_{2}$-horizon.

It is a well accepted view in soil science that in strongly acid soils aluminium acts as an exchangeable base. Therefore, more readily displaceable aluminium compounds may well have contributed to a greater potential soil acidity in the $B_{2}$-horizon as compared with the upper and $\mathrm{B}_{3}$-horizons of the soil profile.

The $\mathrm{pH}-\mathrm{H}_{2} \mathrm{O}$ decreases in the $\mathrm{A}_{2}$-horizon and increases quite markedly again in the $\mathrm{B}_{2}$-horizon. This trend coincides with a similar one in the Ca-saturation. The actual No. of m.e. of $\mathrm{Ca}$ is highest in the $\mathrm{A}_{1}$ and $\mathrm{B}_{2}$-horizons corresponding with a greater saturation as compared with the $\mathrm{A}_{2}$-horizon.

The $A_{2}$-horizon may well be considered as a "bleached" horizon, also commonly met in Red-Yellow podsolics and planosols (PaPADAKIs, 1960), and may thus signify certain reduction processes involved in the soil formation. This appears to be helpful in explaining the genesis of these soils.

Combining these data with the profile morphology, the well drained soil type might well belong to the Group of Yellow Podsolic Soils.

In case of profile (ii) developed on a very poorly drained site, also a distinct increase in clay content occurs with increasing depth. On basis of the zone of gleyification, immediately occuring below the $\mathbf{B}_{1}$-horizon, however, the soil type may be classified accordingly as a hydromorphic soil (SYs, 1959; SEgalen; Anon., 1959).

The occurance of these hydromorphic soils is restricted to poorly drained concave patches in the terrain. The main process of soil formation is apparently podsolisation, which is however obscured by gleyification.

Intergrades present in the sequence may either belong to the Yellow Podsolic or Hydromorphic Soil Group depending of the rate of gleyification.

\section{Genesis}

One of the main characteristics of the soils covering the flat coastal plain is the greater or lesser extent to which the profiles are mottled. It does however not necessarily reflect the present zone of alternating oxidation and reduction.

As has been described before, even in the case of profile (i), a zone of mottling starts at a depth of about $120 \mathrm{~cm}$. Indication of the presence of ground water however has never been assessed by the author when carrying out deep-borings up to 4-5 meters depth. 
At the other hand one may safely assume that conditions of a high ground-water level were prevailing during the gradual regression of the pleistocene sea. The presence of a "bleached" $A_{2}$-horizon strongly points into that direction. However, a gradual rise of the land up to the present altitude above sea-level and influence of "Man" (i.e. drainage) have lowered the present ground-water level to a considerable depth, so that only traces are left of poor drainage conditions in the past.

The formation of the layer of maximum clay accumulation in case of the well drained profile may have been caused either by clay migration (STEPHEN, 1960) or by a breaking down of the clay minerals in the upper layers (VAN SChUYLENBorgh, 1957).

If the latter proves to be the main proces, which still have to be supported by more fundamental data, the relative increase of aluminium in the $B_{2}$-horizon may also be the reflection of kaolinite being synthesised to some extent in that particular layer.

However, the arrangement and thickness of the A and B-horizons certainly do not exclude clay migration from the range of possible processes.

In this respect it is interesting to compare these coastal soils with pleistocene marine soils covering dissected flat plateaux, situated at greater altitudes above sea-level than the former ones discussed in detail in this paper.

Investigation in the latter areas has revealed that podsolisation is also an important process in the soil formation.

Distinction from the coastal soils is however apparent in that the $\mathbf{B}_{2}$-horizon has a thickness commonly exceeding $100 \mathrm{~cm}$ and the presence of a B-consistence horizon rather than a B-structural horizon, corresponding with the layer of maximum clay accumulation. As was shown before, the thickness of the $\mathrm{B}_{2}$-horizon in case of the coastal soil amounted to only $40 \mathrm{~cm}$.

The exchange capacity of the coastal soils differs significantly from and is higher than that of the plateau soils.

The higher exchange capacity of the coastal soils at one hand and the greater thickness of the $B_{2}$-horizon of the plateau soils at the other hand suggest, therefore, a distinct difference in stage of profile development.

Under conditions of high ground-water tables, profile differentiation on level topography diminishes. This factor have certainly contributed to the difference in stage of profile development and consequently to the difference in main processes involved in the formation of the $\mathrm{B}_{2}$-horizon.

Therefore, a breaking down of clay minerals in the upper layers is likely to be the most dominant process in the formation of the $\mathbf{B}_{2}$-horizon of the plateau soils, whereas in case of the coastal soils the process of clay migration still prevails.

\section{ACKNOWLEDGEMENT}

I am indebted to Prof. Dr. C. H. Edelman for his valuable advice and encouragement. My thanks are due to Dr. H. N. Hasselo for his comments on the manuscript, to Mr. F. Hasselaar for his useful assistance in the field work and to the Cameroons Development Corporation for having the soil samples analysed in Ibadan, Nigeria.

\section{REFERENCES}

AHN, P.

Anon.
1959 W.A. Sc. Ass. 5, 1: 10-26.

1959 Soils Map of Africa. Contr. 3rd Inter Afr. Soils Conf. 
Dabin, B., N. Leneuf et G. RIOU

Edelman, C. H.

EVRaRd, C.

EYK, J. J. VAN DER

Hasselo, H. N.

JENNY, H.

Laudelout, H. et al.

MoHr, E. C. J., and F. A. VAN BAREN

PAPADAKIS, J.

RusSEll, E. J., and

E. W. Russell

SEgalen, $P$.

SCHUYLENBORGH, J. VAN

Soil Survey Manual

STEPHEN, I.

Sys, C.

TAN, K. H., and J. VAN SCHUYLENBORGH

VOORDE, P. K. J. VAN DER
ORSTOM Carte pédologique de la République de Côte d'Ivoire au 1/200 000.

$\mathrm{CDC}$ report on The use of aerial survey and soil survey. Appendix.

1957 Bulletin du Jardin bot. de l'Etat, XXVII.

1957 Reconnaissance Soil Survey of Northern Surinam. Thesis, Wageningen.

1961 The soils of the lower eastern slopes of the Cameroon Mountain and their suitability for various perennial crops. Thesis, Wageningen.

1941 Factors of Soil formation. Handbook.

1960 Agricultura Louvain. 8, 103-140, reviewed in Soils and Fertilizers. 23, $4: 248$.

1954 Tropical Soils. Handbook.

1960 Soils and Fertilizers. 23, 240-241.

1956 Soil conditions and piant growth. Handbook, 8th edition.

Etude des sols dérivés de roches volcaniques basique à Madagascar. Thesis, Paris.

1957 Neth. J. Agr. Sc. 5, 3: 195-210.

1958 Neth. J. Agr. Sc. 6, 2: 99-123.

1951 Handbook U.S. Dept. of Agr.

1960 Sci. Progr. London, 48 ; reviewed in Soils and Fertilizers. 23, 4: 251 .

1959 The classification of congolese soils. Contr. 3rd Inter Afr. Soils Conf.

1961 Neth. J. Agr. Sc. 9, $1:$ 41-54.

1957 Soil conditions of the ridge landscape and the old coastal plain of Surinam. Thesis, Wageningen. 